\title{
Peranan Bauran Pemasaran Jasa Pendidikan Terhadap Upaya Meningkatkan Ekuitas Merek Berbasis Pelanggan Perguruan Tinggi (Studi Pada Perguruan Tinggi Di Jawa Barat)
}

\author{
Puspo Dewi Dirgantari \\ Universitas Pendidikan Indonesia \\ puspodewi@upi.edu
}

\begin{abstract}
West Java province dominates the growth rate of universities in Indonesia, but the number of college students has decreasing. Similarly, the people's preference for universities in West Java as an excellent college and the best universities in Indonesia is still low. These problems show that customer based brand equity of colleges in West Java is not optimal. This study conducted in 2013-2014 and uses a management science approach of marketing. The method used in this study is descriptive survey and explanatory survey. The data used primary and secondary data that was collected through questionnaires and documentation. The data analysis used Stuctural Equation Model (SEM). The results of this study revealed that the marketing mix of educational services has a positive influence on the customer based brand equity of higher education in West Java. The dimensions of customer-based brand equity, especially brand performance dimension, should be getting more attention in order to increase performance and the factors are: facilities, meeting the students need, the speed of service, courtesy, and tuition money. This research is part of my dissertation.
\end{abstract}

Keywords:

Marketing Mix of Education Services; Customer Based Brand Equity.

\section{PENDAHULUAN}

Pendidikan Tinggi adalah jenjang pendidikan setelah pendidikan menengah yang mencakup program diploma, program sarjana, program magister, program doktor, dan program profesi, serta program spesialis, yang diselenggarakan oleh perguruan tinggi berdasarkan kebudayaan bangsa Indonesia. Sedangkan Perguruan Tinggi adalah satuan pendidikan yang menyelenggarakan Pendidikan Tinggi. Bentuk Perguruan Tinggi antara lain: (1) Universitas, (2) Institut, (3) Sekolah Tinggi, (4) Politeknik, (5) Akademi, (6) Akademi Komunitas (UU No. 12 Tahun 2012 Pasal 1 Ayat 2).

Setiap tahun perguruan tinggi di Indonesia terus bertambah jumlahnya. Kenaikan ini berdampak pula pada meningkatnya persaingan diantara perguruan tinggi itu sendiri. Lokasi perguruan tinggi di Indonesia untuk tingkat daerah didominasi wilayah provinsi Jawa Barat dan Banten dengan proporsi $15,6 \%$ dari perguruan tinggi di seluruh Indonesia dengan status kepemilikan Perguruan Tinggi Negeri (PTN) dan Perguruan Tinggi Swasta (PTS) (Pikiran Rakyat, 8 April 2010), namun jumlah mahasiswa di perguruan tinggi di Jawa Barat malah menurun.

\section{TABEL 1}

PERKEMBANGAN JUMLAH PERGURUAN TINGGI DI INDONESIA TAHUN 2005 - 2012

\begin{tabular}{|c|c|}
\hline TAHUN & JUMLAH PERGURUAN TINGGI \\
\hline 2005 & 2.428 \\
\hline 2006 & 2.581 \\
\hline 2008 & 2.929 \\
\hline 2010 & 3.098 \\
\hline 2012 & 3.216 \\
\hline
\end{tabular}

Naik turunnya jumlah mahasiswa PTS di Jawa Barat ini disebabkan oleh berbagai faktor antara lain jika dilihat di setiap perguruan tinggi, 
pada tahun 2013 sekitar 55 perguruan tinggi swasta (PTS) di Jawa Barat dalam kondisi kritis karena hanya memiliki sedikit mahasiswa. Bahkan di salah satu PTS jumlah mahasiswanya hanya 50 orang, hal tersebut sangat menyulitkan untuk menjamin keberlangsungan PTS tersebut, karena PTS hidup dari dana mahasiswa dan yayasan. Jika penerimaan mahasiswa sangat sedikit, maka sulit bagi PTS tersebut untuk berkembang. Salah satu yang menyebabkan PTS sulit untuk memperoleh mahasiswa, karena perguruan tinggi negeri (PTN) terlalu banyak menerima mahasiswa baru. Bahkan salah satu PTN bisa menerima hingga 10.000 mahasiswa baru (http://www.klikgalamedia.com/55-pts-di-jabar-kondisi-kritis, Diakses Pada Tanggal 16 Septeber 2013)

TABEL 2 JUMLAH MAHASISWA PTS DI JAWA BARAT TAHUN $2009-2013$

\begin{tabular}{|c|c|}
\hline TAHUN & JUMLAH MAHASISWA \\
\hline 2009 & 398.466 \\
\hline 2010 & 230.564 \\
\hline 2011 & 484.781 \\
\hline 2012 & 520.023 \\
\hline 2013 & 387.628 \\
\hline
\end{tabular}

Sedangkan perkembangan jumlah mahasiswa PTN di Jawa Barat dari tahun 2005 2010 mengalami kenaikan tetapi menurun pada tahun 2011. Pada tahun 2010 sebanyak 181.055 mahasiswa turun menjadi 112.191 mahasiswa. Hal ini menunjukan bahwa kedudukan PTN yang favorit belum tentu selalu baik, karena statusnya yang favorit, dan memilih mahasiswanya selalu yang terbaik, sehingga untuk menghasilkan sarjana-sarjana yang terampil, cerdas, berwawasan luas dan andal itu tidak sulit. Ini membuat PTN terbuai dan lama tidak berusaha melakukan perubahan apa pun untuk bersaing secara nasional dan internasional (Majalah SWA No. 20/XXVII/Tanggal 22 September - 2 Oktober 2011. pp 100).

TABEL 3

JUMLAH MAHASISWA PTN DI JAWA BARAT TAHUN 2005 - 2011

\begin{tabular}{|c|c|}
\hline TAHUN & JUMLAH MAHASISWA \\
\hline 2005 & 27.700 \\
\hline 2006 & 39.400 \\
\hline 2007 & 59.400 \\
\hline 2008 & 80.600 \\
\hline 2009 & 121.255 \\
\hline 2010 & 181.055 \\
\hline 2011 & 112.191 \\
\hline
\end{tabular}

Di saat persaingan antar perguruan tinggi semakin tinggi, peringkat perguruan tinggi di Indonesia khususnya di Jawa Barat menurun di mata dunia termasuk di Asia. Padahal secara implisit Mendiknas Bambang Sudibyo (Kabinet Tahun 2004-2009) menyatakan bahwa pengertian berkualitas atau tidak dari sebuah kampus harus dilihat dari hasil kompetisi antara satu kampus dengan kampus lainnya. Alur logika yang digunakan bahwa kampus berkelas internasional adalah yang memiliki peringkat bagus dalam kompetisi tersebut, dan kompetisi yang dimaksud tiada lain adalah kompetisi internasional. Sedangkan Wakil Rektor Bidang Akademik dan Kemahasiswaan IPB, Yonny Koesmaryono menyatakan bahwa agar 50 universitas unggulan di Indonesia masuk world class university, maka mereka harus berlomba mendapat pengakuan internasional melalui akreditasi internasional. Pengakuan internasional terhadap sebuah universitas akan sangat berdampak positif pada kinerja setiap unit yang harus selalu prima. Pernyataan tersebut juga mengindikasikan perlunya kampus masuk dalam percaturan global dan kemudian dinilai untuk mendapatkan pengakuan lembaga internasional (http://ardianumam.web.ugm.ac.id/?p=2241, Diak ses Pada Tanggal 16 Juli 2014)

Selain itu, masyarakat memiliki preferensi dan persepsi tersendiri dalam menilai suatu perguruan tinggi negeri ataupun swasta. Pada tahun 2013 hanya 2 PTS dan 3 PTN di Jawa Barat yang termasuk PTN dan PTS terfavorit pilihan masyarakat di Indonesia yang secara implisit diidentikan pula sebagai perguruan tinggi terbaik tahun 2013. Hal ini terjadi salah satunya karena kualitas sebagian besar PTS di tanah air khususnya wilayah IV ternyata cukup memprihatinkan. Seperti yang diungkapkan oleh Koordinator Perguruan Tinggi Swasta (Kopertis) Wilayah IV Jawa Barat (Jabar) dan Banten, Abdul Hakim Halim menyebutkan, sebagian besar PTS di wilayahnya masuk kategori tidak sehat. Di wilayah IV ada 466 PTS aktif dan 16 PTS tidak aktif. Jumlah program studi (prodi) mencapai 1.266 unit, yakni 565 unit sedang dalam proses akreditasi, dan 196 unit tidak mengajukan reakreditasi(http://www.kopertis12.or.id/2014/03/ 21/berita-edukasi-20-maret-2014.html, Diakses Pada Tanggal 20 April 2014). Sehingga calon mahasiswa harus benar-benar jeli memilih perguruan tinggi swasta (PTS). 
TABEL 4

PERGURUAN TINGGI TERFAVORIT DI INDONESIA TAHUN 2013

\begin{tabular}{|c|l|l|}
\hline NO & \multicolumn{1}{|c|}{ PTN } & \multicolumn{1}{c|}{ PTS } \\
\hline 1 & Universitas Indonesia & Universitas Trisakti \\
\hline 2 & Univesitas Gajah Mada & Universitas Gunadarma \\
\hline 3 & Institut Teknologi Bandung & IT Telkom \\
\hline 4 & Institut Pertanian Bogor & Universitas Parahyangan \\
\hline 5 & $\begin{array}{l}\text { Institut Teknologi Sepuluh } \\
\text { November }\end{array}$ & Ubinus \\
\hline 6 & Universitas Airlangga & $\begin{array}{l}\text { Universitas Dian } \\
\text { Nuswantoro }\end{array}$ \\
\hline 7 & Universitas Brawijaya & Universitas Tarumanagara \\
\hline 8 & Universitas Diponegoro & STIE Perbanas \\
\hline 9 & Universitas Padjajaran & $\begin{array}{l}\text { Universitas Islam Sultan } \\
\text { Agung }\end{array}$ \\
\hline 10 & Universitas Sumatera Utara & $\begin{array}{l}\text { Universitas Islam } \\
\text { Indonesia }\end{array}$ \\
\hline (Sumber: Pusat Data dan Analisa Tempo, 2013, hal. 81)
\end{tabular}

Sedangkan tingkat awareness atau tingkat pengenalan masyarakat terhadap perguruan tinggi di Indonesia untuk PTN pada peringkat 1 dan 2 adalah Universitas Indonesia dan Universitas Gajah Mada sedangkan untuk PTS adalah IT Telkom dan Universitas Gunadarma. Hal ini menunjukan bahwa perguruan tinggi-perguruan tinggi tersebut yang paling diingat keberadaannya oleh masyarakat. Dari 457 PTS di Jawa Barat dan Banten hanya IT Telkom yang masuk 12 teratas perguruan tinggi yang paling diingat oleh masyarakat dan 3 PTN dari 9 PTN di Jawa Barat dan Banten yang masuk 12 teratas perguruan tinggi yang paling diingat oleh masyarakat yaitu Institut Teknologi Bandung (ITB), Institut Pertanian Bogor (IPB) dan Universitas Padjajaran (Unpad).

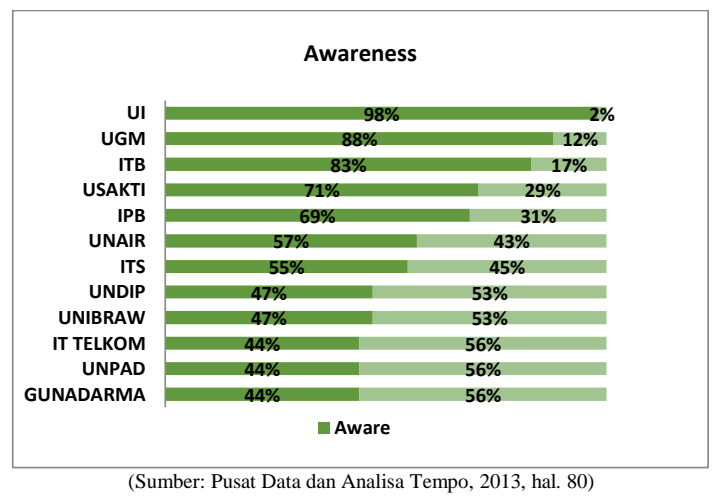

GAMBAR 1

\section{TINGKAT AWARENESS MASYARAKAT TERHADAP PERGURUAN TINGGI DI INDONESIA TAHUN 2013}

Tingkat awareness atau pengenalan masyarakat terhadap nama-nama perguruan tinggi tersebut diukur dalam tiga level, yaitu top of mind (TOM), spontanitas, dan aided. Level pertama adalah nama perguruan tinggi yang disebut pertama kali. Ini level tertinggi karena menunjukkan nama yang paling diingat dan tertanam di benak. Level kedua menunjukkan semua nama yang diingat secara spontan tanpa dibantu, hanya diberi waktu untuk mengingat. Adapun level ketiga adalah level terendah penyebutan nama dengan alat bantu berupa showcard atau dengan bantuan penyebutan nama.

Berdasarkan Gambar 2 Universitas Indonesia (UI) memiliki tingkat awareness paling tinggi, dikenal oleh $98 \%$. Berarti hanya $2 \%$ yang tidak mengenal universitas itu. Universitas Gadjah Mada (UGM) berada di urutan kedua, dikenal oleh $88 \%$. Urutan ketiga dan keempat diduduki Institut Teknologi Bandung (83\%) dan Universitas Trisakti (71\%). Komposisi terbesar UI berada pada level spontanitas (65\%). Artinya, kelompok ini tidak menyebut UI pertama kali, tapi UI tetap disebut setelah mereka menyebutkan nama-nama perguruan tinggi lain lebih dulu. Level yang benarbenar menyebut UI pertama kali (TOM) mencapai $25 \%$ dan hanya $8 \%$ yang memerlukan bantuan.

Sedangkan komposisi terbesar UGM berada pada level spontanitas (57\%). Komposisi aided lebih besar dibanding UI, yaitu 19\%. Level yang benar-benar menyebut yang benar-benar menyebut UGM pertama kali (TOM) lebih kecil daripada UI, mencapai $12 \%$. Hal ini menunjukan bahwa persepsi masyarakat terhadap perguruan tinggi berdasarkan pengetahuan dan pengalaman mereka khususnya untuk perguruan tinggi di Jawa Barat belum optimal, padahal di era kompetisi seperti saat ini, perguruan tinggi khususnya swasta berlomba-lomba mempromosikan diri untuk menarik minat calon mahasiswa. Meskipun PTN masih diminati, kehadiran PTS yang semakin banyak dengan pilihan beragam jurusan dapat menambah alternatif pilihan (Pusat Data dan Analisa, 2013:80).

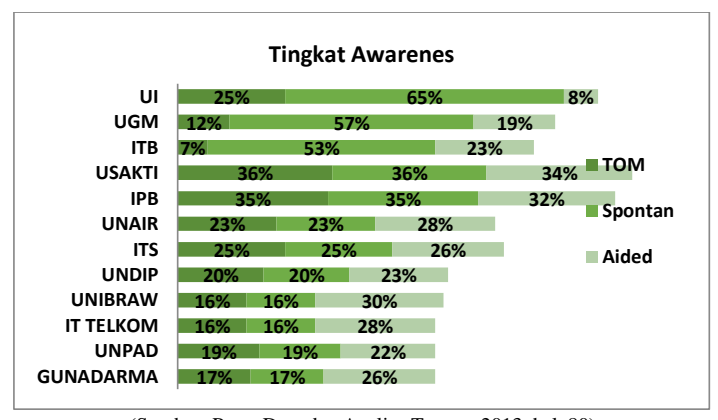

(Sumber: Pusat Data dan Analisa Tempo, 2013, hal. 80)

GAMBAR 2 


\section{PEMBAGIAN TINGKAT AWARENESS MASYARAKAT TERHADAP PERGURUAN TINGGI DI INDONESIA TAHUN 2013}

Beberapa hal tersebut menunjukan adanya permasalahan belum optimalnya ekuitas merek berbasis pelanggan perguruan tinggi di Jawa Barat. Ekuitas merek adalah serangkaian aset dan kewajiban merek yang berkaitan dengan sebuah merek, nama dan simbolnya, yang menambah atau mengurangi nilai yang diberikan pada sebuah produk atau jasa kepada perusahaan atau para pelanggan perusahaan (Aaker, DA, 1997:22). Ketika mencerminkan konsumen atau perspektif pemasaran, ekuitas merek disebut sebagai ekuitas merek berbasis konsumen. Mackay et al. (1997, hal. 153) dalam Ravi Pappu, Pascale G. Quester \& Ray W. Cooksey (2005) menyatakan bahwa pendekatan pemasaran (sering disebut sebagai ekuitas merek berbasis konsumen) mengacu pada nilai tambah merek kepada konsumen. Pendekatan pelanggan ini cenderung berfokus pada nilai yang diciptakan oleh kegiatan pemasaran seperti yang dirasakan oleh pelanggan.

Ekuitas merek berbasis-pelanggan (customer-based brand equity) merupakan pengaruh diferensial yang dimiliki pengetahuan merek atas respons konsumen terhadap pemasaran merek tersebut (Philip Kotler \& Kevin Lane Keller, 2009:263). Pengetahuan merek menciptakan sumber utama untuk ekuitas merek berbasis pelanggan. Pengetahuan merek terdiri dari (1) brand awareness, yang berkaitan dengan kemampuan untuk mengenali atau mengingat merek dan (2) brand image, yang terdiri dari persepsi konsumen dan asosiasi untuk merek (Keller, 1998, hal. 94) dalam Pekka Tuominen (2000).

Kevin Lane Keller (2013:550-551) juga berpendapat bahwa dalam membangun ekuitas merek berbasis pelanggan juga harus memperhatikan pengembangan program pemasaran seperti (1) memastikan persepsi kualitas tingkat tinggi dan menciptakan citra merek yang kaya dengan menghubungkan asosiasi yang terkait dengan produk - tangible dan intangible untuk merek, (2) mengadopsi strategi harga, (3) mempertimbangkan berbagai pilihan distribusi langsung dan tidak langsung, (4) mix pilihan komunikasi pemasaran, (4) memanfaatkan secondary associations untuk mengimbangi dimensi yang hilang dari program pemasaran dengan menghubungkan merek ke entitas lain seperti perusahaan, saluran distribusi, merek lain, karakter, juru bicara atau endorser lain, atau peristiwa yang memperkuat dan meningkatkan citra merek.

Elemen bauran pemasaran memberikan kontribusi terhadap ekuitas merek berbasis pelanggan (Hui-Chu Chen \& Robert D. Green, 2011). Bauran pemasaran merupakan seperangkat alat pemasaran taktis yang dipadukan oleh perusahaan untuk menghasilkan respon yang diinginkan dalam target pasar. Bauran pemasaran terdiri dari semua tindakan yang dapat dilakukan perusahaan untuk mempengaruhi permintaan atas produknya (Philip Kotler \& Amstrong, 2012:51). Bauran pemasaran jasa pendidikan terdiri atas: (1) Produk Jasa, (2) Tarif Jasa, (3) Tempat/Lokasi Pelayanan, (4) Promosi, (5) Orang/Partisipan, (6) Sarana Fisik, dan (7) Proses (Buchari Alma dan Ratih Hurriyati, 2008:154).

Beberapa program bauran pemasaran yang dilakukan oleh perguruan tinggi di Jawa Barat antara lain setelah melakukan beberapa kali rapat dengan pimpinan fakultas, akhirnya UNPAD tidak mensyaratkan bebas difabel pada SNMPTN 2014. Artinya, mereka yang memiliki cacat fisik boleh mendaftar ke seluruh prodi yang ditawarkan UNPAD. Warek Bidang Pembelajaran dan Kemahasiswaan, Prof. Dr. H. Engkus Kuswarno, M.S menyampaikan bahwa semula seluruh prodi (45 prodi) masih mensyaratkan harus bebas difabel (bebas ketunaan atau calon yang cacat fisik tidak boleh mendaftar). Pada surat tanggal 10 Maret 2014 UNPAD menyisakan 21 prodi (jumlah prodi pada kelompok Saintek) yang masih memberikan syarat bebas buta warna untuk pendaftaran SNMPTN 2014 (http://www.kopertis12.or.id/2014/03/21/beritaedukasi-20-maret-2014.html, Diakses Pada Tanggal 10 Juli 2014).

Perguruan Tinggi Swasta (PTS) di Jawa Barat akan mendapat alokasi pengembangan Ruang Kuliah Baru (RKB) dari Pemerintah Provinsi Jawa Barat. Untuk tahun 2013 Gubernur Jawa Barat berencana mengalokasikan Rp 300 juta untuk masing-masing PTS di Jawa Barat yang jumlahnya mencapai 350 institusi. Totalnya kurang lebih Rp 100 miliar. Masing-masing dapat sekitar tiga ruang kuliah baru. Program tersebut merupakan kelanjutan dari peningkatan kualitas pendidikan di Jawa Barat, terutama pembangunan Ruang Kuliah Baru (http://www.jabarprov.go.id/index.php/news/5447 /Heryawan_Siapkan_100_Miliar_Bangun_RKB_ PTS, Diakses Pada Tanggal 19 Maret 2014). 
Sebanyak 30 perguruan tinggi di Jawa Barat dan pemerintah propinsi Jawa Barat menandatangani $\mathrm{MoU}$ program Kuliah Kerja Nyata (KKN) Tematik. Penandatanganan dilakukan oleh Gubernur Jawa Barat, Ahmad Heryawan dan pimpinan perguruan tinggi. KKN Tematik adalah KKN yang orientasi program kegiatannya terfokus untuk mengatasi masalah kronis yang memerlukan pemecahan masalah (problem solving) melalui 40 kegiatan tematik(http://braderdennis.blogspot.co.id/2011/1 2/1321.html, Diakses Pada Tanggal 18 Juli 2014).

Berdasarkan latar belakang tersebut, maka perlu diadakan penelitian mengenai: Peranan Bauran Pemasaran Jasa Pendidikan Terhadap Upaya Meningkatkan Ekuitas Merek Berbasis Pelanggan Perguruan Tinggi (Studi Pada Perguruan Tinggi Di Jawa Barat)

\section{KAJIAN TEORITIS}

Pemasaran adalah kegiatan/aktivitas, mengatur lembaga, dan proses untuk menciptakan, mengkomunikasikan, memberikan dan bertukar penawaran yang memiliki nilai bagi pelanggan, klien, mitra dan masyarakat pada umumnya (Philip Kotler \& Kevin Lane Keller, 2009:5). "Marketing is the process by which companies create value for customers and build strong customer relationships in order to capture value from customers in return" (Philip Kotler \& Amstrong, 2012:27).

Jasa (service) adalah semua tindakan atau kinerja yang dapat ditawarkan satu pihak ke pihak lain yang pada intinya tidak berwujud dan tidak menghasilkan kepemilikan apapun (Philip Kotler \& Kevin Lane Keller, 2009:410). Secara garis besar, menurut Zeithaml dalam Buchari Alma (2007:250) jasa dikelompokan ke dalam berbagai jenis, yaitu: 1) Transportasi termasuk didalamnya kereta api, bus, truk, transportasi air, udara dan sebagainya, 2) Komunikasi berupa telepon, radio, dan televisi, 3) Public utilities berupa listrik, gas, dan kebersihan, 4) Perdagangan besar termasuk agen-agen dari produsen, 5) Perdagangan eceran termasuk didalamnya berbagai bentuk pertokoan, 6) Keuangan, asuransi, dan perumahan berupa simpan pinjam, bursa efek, perusahaan investasi, usaha pembangunan perumahan, 7) Jasa hotel, 8) Personal services, 9) Business services, 10) Jasa parker, 11) Jasa bengkel/reparasi, 12) Jasa bioskop hiburan dan rekreasi, 13) Jasa di bidang kesehatan, 14) Jasa dibidang hukum, 15) Jasa pendidikan, 16) Jasa sosial atau masyarakat, 17) Jasa organisasi,
18) Jasa yang ditawarkan oleh pemerintah, perizinan, keamanan polisi/TNI dan sebagainya Pemasaran dalam bidang pendidikan menghasilkan kepuasan mahasiswa serta kesejahteraan stakeholder lembaga pendidikan dalam jangka panjang sebagai kunci untuk memperoleh profit. Hal ini berlaku bagi lembaga pendidikan yang bergerak di bidang industri jasa pendidikan maupun maupun industri jasa non pendidikan. Walaupun terdapat kesamaan tujuan pada kedua jenis industri tersebut, diperlukan strategi pemasaran yang berbeda untuk masingmasing jenis industri. Perbedaan strategi tersebut dipengaruhi oleh ciri-ciri dasar yang berbeda dari jenis produk yang dihasilkan.

Strategi pemasaran mengacu pada pola terpadu organisasi untuk menentukan keputusan penting yang menyangkut perilaku pemasaran atau tindakan yang ditujukan pada pelanggan untuk efek afektif tertentu, kognitif dan kecenderungan perilaku pada mereka menuju penawaran produk dalam rangka memfasilitasi mereka terlibat dalam menghasilkan pendapatan transaksional dan pertukaran relasional dengan organisasi dan dengan demikian memungkinkan organisasi untuk mencapai tujuan tertentu (Venkatesh Shankar dan Gregory S. Carpenter, 2012:24). Sedangkan Philip Kotler \& Amstrong (2008:58) menyatakan bahwa "marketing strategy is the marketing logic by which the company hopes to create customer value and achieve profitable customer relationships". Pada dasarnya strategi pemasaran memberikan arah dalam kaitannya dengan variabel-variabel seperti segmentasi pasar, identifikasi pasar sasaran, positioning, elemen bauran pemasaran, dan biaya bauran pemasaran. Strategi pemasaran merupakan bagian integral dan strategi bisnis yang memberikan arah pada semua fungsi manajemen suatu organisasi (Fandy Tjiptono, 2008:6).

Proses strategi pemasaran terdiri atas: (1) Market, Segments And Customer Valuemempertimbangkan pasar dan analisis pesaing, segmentasi pasar, manajemen hubungan pelanggan strategis, dan terus-menerus mempelajari tentang pasar, (2) Designing Market Driven Strategy-meneliti konsumen sasaran dan strategi positioning, strategi pemasaran hubungan dan inovasi serta strategi produk baru, (3) Market Driven Program Development-terdiri dari merek, rantai nilai, harga, promosi dan rancangan strategi penjualan dan melaksanakan syarat kebutuhan konsumen sasaran, (4) Implementing And Managing Market Driven Strategies-implementasi dan pengawasan rancangan organisasi dan strategi 
pemasaran (David W Cravens \& Nigel Piercy, 2009:13).

Bauran pemasaran adalah kombinasi dari produk, sistem distribusi, struktur harga dan kegiatan promosi (Ashok Jain, 2009:77). "Marketing mix is the set of tactical marketing tools-product, price, place, and promotion-that the firm blends to produce the response it wants in the target market" (Philip Kotler \& Amstrong, 2012:76). Bauran pemasaran adalah seperangkat alat pemasaran terkendali yang digunakan institusi untuk memproduksi/menghasilkan respon yang diinginkan dari berbagai target pasar (Jonathan Ivy, 2008).

Sedangkan bauran pemasaran jasa pendidikan adalah elemen-elemen organisasi pendidikan yang dapat dikontrol oleh organisasi dalam melakukan komunikasi dengan peserta didik dan akan dipakai untuk memuaskan peserta didik (Buchari Alma dan Ratih Hurriyati, 2008:154). Jonathan Ivy (2008) menyatakan bahwa dalam Business School 7P Marketing Mix terdiri atas: (1) Premiums (Premi), (2) Prominence (Keahlian/Keunggulan), (3) Promotion (Promosi), (4) Prospectus, (5) Price (Harga), (6) Programme (Program), (7) People (Orang)

Salah satu aset tak berwujud adalah ekuitas yang diwakili oleh merek. Bagi banyak perusahaan, merek dan segala yang diwakilinya merupakan aset yang paling penting karena dasar keuntungan kompetitif dan sumber penghasilan masa depan. Namun, merek-merek jarang dikelola secara terkoordinasi, dan tidak ada sikap koheren yang memandang aset tersebut memang semestinya dijaga dan diperkokoh (Aaker, DA, 1997:20). Karena itu, tantangan bagi pemasar dalam membangun merek yang kuat adalah memastikan bahwa pelanggan memiliki jenis pengalaman yang tepat dengan produk, jasa dan program pemasaran mereka untuk menciptakan pengetahuan merek yang diinginkan. Pengetahuan konsumen-lah yang menimbulkan perbedaanperbedaan yang kemudian memanifestasikan diri dalam ekuitas merek. Dalam pengertian abstrak, kita dapat menganggap ekuitas merek sebagai alat yang memberikan "jembatan" strategi vital kepada pemasar dari masa lalu mereka ke masa depan (Philip Kotler \& Kevin Lane Keller, 2009:264).

Pemasar dan periset menggunakan berbagai perspektif untuk mempelajari ekuitas merek. Pendekatan berbasis pelanggan memandang ekuitas merek dari perspektif konsumen - baik perorangan maupun organisasi. Prinsip dari model ekuitas merek berbasis pelanggan adalah bahwa kekuatan merek terletak pada apa yang dilihat, dibaca, didengar, dipelajari, dipikirkan, dan dirasakan pelanggan tentang merek sepanjang waktu.

Ekuitas merek berbasis-pelanggan (customer-based brand equity) adalah pengaruh diferensial yang dimiliki pengetahuan merek atas respons konsumen terhadap pemasaran merek tersebut. Sebuah merek mempunyai ekuitas merek berbasis pelanggan yang positif ketika konsumen bereaksi lebih positif terhadap produk dan cara produk itu dipasarkan ketika merek itu teridentifikasi, dibandingkan ketika merek itu tidak teridentifikasi. Merek mempunyai ekuitas merek berbasis pelanggan yang negatif jika konsumen tidak terlalu menyukai aktivitas pemasaran untuk merek itu dalam keadaan yang sama (Philip Kotler \& Kevin Lane Keller, 2009:263).

\section{METODE PENELITIAN}

Penelitian ini merupakan bagian dari penelitian disertasi S3, yang dijadikan independent variables (variabel bebas) adalah bauran pemasaran jasa pendidikan dan dependent variable (variabel terikat) adalah ekuitas merek berbasis pelanggan. Berdasarkan tujuan penelitian, penelitian ini bersifat penelitian deskriptif dan verifikatif dengan metode penelitian yang digunakan adalah metode explanatory survey dan ditinjau dari sisi rentang waktu (time horizon), penelitian ini tergolong cross sectional studies, pengumpulan data dari responden dilakukan pada tahun 2014.

Bentuk uji statistika yang digunakan yaitu model persamaan struktural atau Structural Equation Modeling (SEM). Populasi dalam penelitian ini adalah mahasiswa aktif angkatan tahun 2008-2012 di perguruan tinggi negeri dan swasta di Jawa Barat sebanyak 540.087 orang mahasiswa dengan ukuran sampel sebanyak 400 orang responden. Hipotesis yang diajukan penulis sebagai berikut:

$\mathrm{H}_{0}$ : Bauran pemasaran jasa pendidikan tidak berpengaruh terhadap ekuitas merek berbasis pelanggan perguruan tinggi baik secara simultan maupun parsial

$\mathrm{H}_{1}$ : Bauran pemasaran jasa pendidikan berpengaruh terhadap ekuitas merek berbasis pelanggan perguruan tinggi baik secara simultan maupun parsial 


\section{HASIL PENELITIAN DAN PEMBAHASAN}

\section{Gambaran Bauran Pemasaran Jasa Pendidikan Perguruan Tinggi Di Jawa Barat}

Gambaran bauran Pemasaran Jasa Pendidikan dilakukan melalui enam dimensi yaitu Programme, Prospectus, Price, Prominence, People, Promotion dan Premiums.

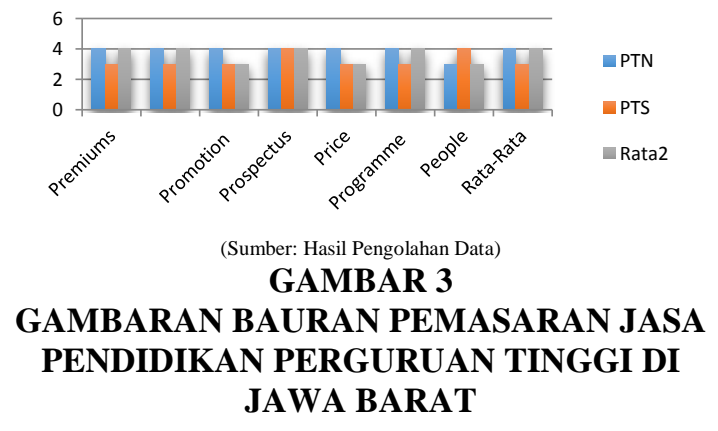

Berdasarkan data yang diperoleh di lapangan, pendapat mahasiswa yang banyak menilai tinggi adalah untuk tingkat ketersediaan akomodasi mahasiswa (tempat ibadah, tempat makan/kantin, asrama, dan lain-lain) pada dimensi premiums, rasio kualifikasi dosen S2, S3, Guru Besar atau Profesor pada dimensi prominance, penggunaan electronic media/media elektronik dalam mempromosikan perguruan tinggi pada dimensi promotion, penggunaan prospectus/brosur dalam mempromosikan perguruan tinggi pada dimensi prospectus, dan ketersediaan layanan pembelajaran tatap muka langsung dalam perkuliahan pada dimensi people. Sedangkan tingkat kesesuaian durasi/lamanya masa studi dengan standar nasional pendidikan tinggi pada dimensi price dan variasi pilihan jenjang pendidikan di perguruan tinggi pada dimensi programme banyak dinilai cukup tinggi oleh mahasiswa.

Jika berdasarkan skor perolehan tanggapan mahasiswa terhadap bauran pemasaran jasa pendidikan perguruan tinggi di Jawa Barat yaitu 34.132 dibandingkan skor ideal yaitu 48.000 untuk 24 item pertanyaan maka bauran pemasaran jasa pendidikan perguruan tinggi di Jawa Barat termasuk kategori tinggi, berarti bahwa penggunaan dan/atau pelaksanaan bauran pemasaran jasa pendidikan di perguruan tinggi di Jawa Barat dapat memenuhi kebutuhan dan keinginan mahasiswa. Mahasiswa dapat menggunakan infrastruktur TI maupun kelengkapan akomodasi lainnya di lingkungan perguruan tinggi. Kelengkapan buku perpustakaan dan sistem onlinenya memudahkan mahasiswa untuk mencari bahan yang diperlukan, sistem pembayaran kuliah, beragam/variasi jenjang pendidikan dan jurusan atau program studi dan sebagainya.

\section{Gambaran Ekuitas Merek Berbasis Pelanggan Perguruan Tinggi Di Jawa Barat}

Gambaran ekuitas merek berbasis pelanggan perguruan tinggi di Jawa Barat dilakukan melalui brand salience, brand performance, brand imagery, brand judgement, brand feeling, dan brand resonance.

Berdasarkan data yang diperoleh di lapangan, pendapat mahasiswa yang paling banyak menilai tinggi adalah untuk frekuensi mahasiswa mendengar perguruan tinggi pada dimensi brand saliance dan banyaknya mahasiswa yang kuliah di perguruan tinggi pada dimensi brand imagery. Sedangkan tingkat kesukaan mahasiswa atas design/rancangan perguruan tinggi pada dimensi brand performance, pemenuhan kebutuhan mahasiswa oleh perguruan tinggi, kesesuaian perguruan tinggi dengan kepribadian mahasiswa dan rasio/perbandingan kelebihan/keunggulan dari perguruan tinggi dengan perguruan tinggi lain pada dimensi brand judgement, kebanggan yang dirasakan mahasiswa saat kuliah di perguruan tinggi sehingga membuat mahasiswa merasa lebih baik tentang diri mereka sendiri pada dimensi brand feeling, perbedaan jika perguruan tinggi ini tidak ada dan harus kuliah di perguruan tinggi lain, keistimewaan perguruan tinggi bagi mahasiswa, kesamaan memilih perguruan tinggi dengan mahasiswa lain dan perbandingan keingintahuan mahasiswa tentang informasi perguruan tinggi dibandingkan dengan orang lain pada dimensi brand resonance banyak dinilai cukup tinggi oleh mahasiswa.

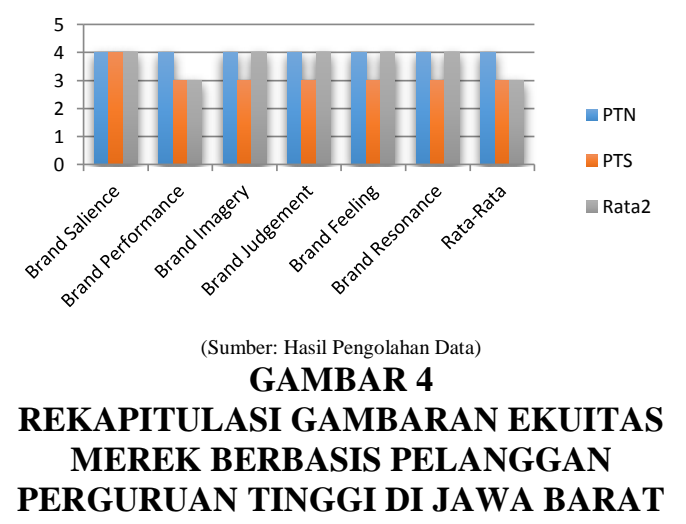


Jika berdasarkan skor perolehan tanggapan mahasiswa terhadap ekuitas merek berbasis pelanggan perguruan tinggi di Jawa Barat yaitu 103.464 dibandingkan skor ideal yaitu 148.000 untuk 74 item pertanyaan maka ekuitas merek berbasis pelanggan perguruan tinggi di Jawa Barat termasuk kategori cukup tinggi, hal ini berarti bahwa perguruan tinggi di Jawa Barat memiliki kekuatan merek yang cukup tinggi di mata mahasiswa setelah mereka melihat, mendengar, mempelajari, memikirkan dan merasakan langsung jasa pendidikan perguruan tinggi di Jawa Barat.

Merek yang kuat mempunyai ekuitas merek yang tinggi. Ekuitas merek adalah pengaruh diferensial positif bahwa jika pelanggan mengenal nama merek, pelanggan akan merespon produk atau jasa. Satu ukuran ekuitas merek adalah sejauh mana pelanggan bersedia membayar lebih untuk merek tersebut (Philip Kotler \& and Amstrong, 2008:282). Premis dasar dari model ekuitas merek berbasis pelanggan adalah bahwa kekuatan merek terletak pada apa yang pelanggan telah pelajari, merasakan, melihat, dan mendengar tentang merek dari waktu ke waktu. Dengan kata lain, kekuatan merek berada dalam benak pelanggan (Kevin Lane Keller, 2001).

Pengaruh Bauran Pemasaran Jasa Pendidikan Terhadap Ekuitas Merek Berbasis Pelanggan Perguruan Tinggi Di Jawa Barat

Hasil pengujian pengaruh bauran pemasaran jasa pendidikan (BPJP) terhadap ekuitas merek berbasis pelanggan (EMBP) ditunjukan dengan menganalisis nilai regresi (regression weights analisis structural equation modeling) dimana $\mathrm{CR}$ dan nilai $\mathrm{P}$ hasil olah data dibandingkan dengan batasan statistik yang disyaratkan yaitu untuk nilai CR > 1,978 dan untuk nilai $\mathrm{P}<0,05$. Pengaruh Bauran Pemasaran Jasa Pendidikan (BPJP) terhadap Ekuitas Merek Berbasis Pelanggan (EMBP) memiliki standardized estimate (regression weight) sebesar 0,206 atau 20,6\% dengan nilai CR 3,271>1,978 dan P $0,001 \leq 0.05$ berarti Bauran Pemasaran Jasa Pendidikan (BPJP) berpengaruh secara signifikan terhadap Ekuitas Merek Berbasis Pelanggan (EMBP). Nilai yang positif menunjukan bahwa perguruan tinggi yang telah mempertimbangkan bauran pemasaran jasa pendidikan dengan baik pada umumnya cenderung akan memiliki ekuitas merek berbasis pelanggan yang lebih baik.

Bauran pemasaran memberikan kontribusi terhadap ekuitas merek berbasis pelanggan (Hui-Chu Chen \& Robert D. Green, 2011). Kegiatan bauran pemasaran dapat menciptakan hubungan yang lebih dekat antara kedua fungsi di mana strategi pemasaran bagi perusahaan menggunakan/memanfaatkan bauran pemasaran (harga, kualitas produk, promosi dan tempat/distribusi) untuk membuat dampak yang berbasis konsumen dan posisi merek dalam pola pikir konsumen. Hal ini akan menyebabkan dampak yang berbasis keuangan bahwa hasil keuangan atau imbalan menyebabkan siklus untuk mempertahankan investasi dalam merek (Jürgen Abele, Len Tiu Wright, David Pickton, Kaouther Kooli, 2006).

\section{KESIMPULAN DAN REKOMENDASI}

Bauran pemasaran jasa pendidikan perguruan tinggi di Jawa Barat dinilai tinggi, berarti bahwa penggunaan dan/atau pelaksanaan bauran pemasaran jasa pendidikan di perguruan tinggi di Jawa Barat dapat memenuhi kebutuhan dan keinginan mahasiswa. Demikian pula dengan ekuitas merek berbasis pelanggan perguruan tinggi di Jawa Barat memiliki kekuatan merek yang dinilai tinggi di mata mahasiswa setelah mereka melihat, mendengar, mempelajari, memikirkan dan merasakan langsung jasa pendidikan perguruan tinggi di Jawa Barat

Perguruan tinggi di Jawa Barat diharapkan dapat terus meningkatkan: pemanfaatan brosur, direct mail, press advertising, publicity dan electronic media, layanan pembelajaran tatap muka langsung perkuliahan, ketersediaan kontak personal dosen, karyawan dan ketersediaan informasi setiap saat, reputasi staf akademik, rasio kualifikasi dosen S2, S3 Guru Besar atau Profesor, partisipasi perguruan tinggi dalam perkumpulan antar perguruan tinggi dan informasi online

\section{DAFTAR PUSTAKA}

Aaker, DA. Alih Bahasa Oleh Aris Ananda. (1997). Manajemen Ekuitas Merek. Jakarta: Spektrum.

Ashok Jain. (2009). Principles of Marketing. India. V.K. New Delhi: Enterprises.

A.Mohammad BS. (2011). Aneka Strategi PT Lokal Menjawab Tantangan PT Asing. Majalah SWA No. 20/XXVII/Tanggal 22 
September - 2 Oktober 2011. pp 100. Jakarta: Sembada Swakarya.

Buchari Alma. (2007). Manajemen Pemasaran dan Pemasaran Jasa. Bandung: Alfabeta.

Buchari Alma dan Ratih Hurriyati. (2008). Manajemen Corporate dan Strategi Pemasaran Jasa Pendidikan. Bandung: Alfabeta.

Cimincrang (GM). 55 PTS di Jabar Kondisi Kritis. Artikel Diakses Pada Tanggal 16 September 2013 Dari Website http://www.klik-galamedia.com/55-pts-dijabar-kondisi-kritis

David W Cravens \& Nigel Piercy. (2009). Strategic Marketing. Boston: McGraw Hill Irwin.

Edi Subkhan. (2010). Sebuah Studi Analisis: Mempertanyakan Orientasi World Class University*. Disampaikan Pada Seminar Nasional BEM FE Unsoed, 30 Oktober 2010. Artikel Diakses Pada Tanggal 16 Juli 2014

DariWebsite http://ardianumam.web.ugm.ac.id/?p=2241

Fandy Tjiptono. (2008). Strategi Pemasaran. Yogyakarta: Andi.

Hui-Chu Chen \& Robert D. Green. (2011). Brand Equity, Marketing Strategy, And Consumer Income: A Hypermarket Study. Journal of Management and Marketing Research. September 2011, Vol. 8, p1. http://www.aabri.com/ manuscripts/11828.pdf

Jonathan Ivy. (2008). A New Higher Education Marketing Mix: The 7Ps For MBA Marketing. Birmingham City University. Birmingham. UK. International Journal of Educational Management Vol. 22 No. 4, 2008 pp. 288-289 (C) Emerald Group Publishing Limited.

Jürgen Abele, Len Tiu Wright, David Pickton, Kaouther Kooli. (2006).Brand Equity with an Improved Role for the Marketing Mix in a Practice-oriented Brand Valuation. Framework. Leicester Business School, Faculty of Business and Law, Hugh Aston Building, De Montfort University. The Gateway, Leicester, LE1 9BH, UK. Email: lwright@dmu.ac.uk. http://www.brandmanagement.usi.ch/Abstracts/Monday/Bra ndEquity2/Monday_BrandEquityII_Abele. pdf.

Kementerian Riset, Teknologi dan Pendidikan Tinggi, Koordinasi Perguruan Tinggi Swasta Wilayah XII Maluku. (2014). 70\%
PTS Belum Akreditasi Ribuan Mahasiswa Terancam Gagal Wisuda. Artikel Diakses Pada Tanggal 20 April 2014 Dari Website http://www.kopertis12.or.id/2014/03/21/be rita-edukasi-20-maret-2014.html

Kementerian Riset, Teknologi dan Pendidikan Tinggi, Koordinasi Perguruan Tinggi Swasta Wilayah XII Maluku. (2014). Unpad Cabut Syarat Bebas Difabel untuk SNMPTN. Artikel Diakses Pada Tanggal 10 Juli $2014 \quad$ Dari Website http://www.kopertis12.or.id/2014/03/21/be rita-edukasi-20-maret-2014.html

Kevin Lane Keller. (2001). Building CustomerBased Brand Equity: A Blueprint For Creating Strong Brands, Working Paper, report No. 01-107, Marketing Science Institute 1000 Massachusetts Avenue, Cambridge MA 02138 USA, 617.491.2060, www.msi.org.

Kevin Lane Keller. (2013). Strategic Brand Management: Building, Measuring, and Managing Brand Equity. England: Perason Education Limited.

Pemerintah Propinsi Jawa Barat. (2014). Heryawan Siapkan 100 Miliar Bangun RKB PT. Artikel Diakses Pada Tanggal 19 Maret $2014 \quad$ Dari Website http://www.jabarprov.go.id/index.php/new s/5447/Heryawan_Siapkan_100_Miliar_B angun_RKB_PTS

Pemerintah Jawa Barat Dan Perguruan Tinggi Tandatangani Mou Program Kuliah. (2011). Diposkan oleh M. Denis Caesar. Artikel Diakses Pada Tanggal 18 Juli 2014 Dari Website http://braderdennis.blogspot.co.id/2011/12/ 1321.html

Philip Kotler \& and Amstrong. (2008). PrinsipPrinsip Pemasaran Edisi 12. Jakarta: Erlangga.

Philip Kotler \& Amstrong. (2012). Principles Of Marketing 14ed. USA: Pearson Education.

Philip Kotler \& Kevin Lane Keller. (2009). Manajemen Pemasaran Edisi Ketiga Belas. Jakarta: Erlangga.

Pikiran Rakyat (Koran) Tanggal 08 April 2010

Pusat Data dan Analisa. (2013). Panduan Memilih Perguruan Tinggi 2013 Edisi Ke18. Jakarta: Pusat Data dan Analisa Tempo.

Ravi Pappu, Pascale G. Quester, Ray W. Cooksey. (2005). Consumer-Based Brand Equity: Improving The Measurement Empirical Evidence. Journal of Product \& 
Brand Management Volume $14 \cdot$ Number 3 . 2005 · 143-154 (C) Emerald Group Publishing Limited [ISSN 1061-0421] [DOI 10.1108/10610420510601012].

Tuominen, P. (2000). Customer-Based Brand Equity: Delivering Value For The Firm, Trade And Customer. Management Expertise For The Millennium, Series A-1: 2000. pp 305-316.

Undang-Undang Nomor 12 Tahun 2012 Tentang Pendidikan Tinggi Pasal 1 Ayat 2

Venkatesh Shankar dan Gregory S. Carpenter. (2012). Handbook Of Marketing Strategy. UK: Edward Elgar Publishing Limited. 